\title{
THE INTERNET, CIVIC ENGAGEMENT, AND NEW CIVIL SOCIETY IN INDONESIA: A LESSON FROM TWO TALES
}

\section{Dani Muhtada}

Faculty Of Law Semarang State University

JL. Sekaran, Semarang, Central Java, 50229, Indonesia

Telp./Fax: +62-24-8507891 Email: dmuhtada@mail.unnes.ac.id

Submitted: Jun 13, 2018; Reviewed: Jun 28, 2018; Accepted: Jun 29, 2018

\begin{abstract}
This article discusses two legal cases happened in 2009: the cases of Prita Mulyasari and Bibit-Chandra. These cases are interesting as they involved the use of Internet as a medium for an effective civic engagement in controlling law enforcement. The response of the Indonesian public to the cases of Prita and Bibit-Chandra and their success stories in controlling the authorities indicate a significant existence of the so-called an "online parliament", which signed an emergence of a new civil society movement in the modern Indonesia. This online parliament is much more inexpensive and independent than the conventional parliament. However, it might only work for political issues that attract much public attention and might be only accessible for those who have the access to the Internet.
\end{abstract}

Keywords: Civic Engagement, Civil Society, Law Enforcement, The Internet

\section{INTRODUCTION}

About ten years ago, two similar cases had attracted a lot of public attention in Indonesia: The Cases of Prita Mulyasari and Bibit-Chandra. Prita Mulyasari was a mother of two who was captured and detained by the municipal prosecutors because of her email complaining about a hospital's service. Bibit and Chandra are two deputy chairmen of Indonesia's Corruption Eradication Commission (KPK) who were arrested by the police on charges of abuse of power and extortion related to a graft investigation against Anggoro Widjojo, fugitive businessman. While the former happened in June, or just a month before the presidential election, the latter happened in October, or nine days after Susilo Bambang Yudhoyono (SBY) was inaugurated as the President for his second term.

These cases are interesting because they involved the use of internet by society to reach their goals. In the case of Prita, a Facebook group made for her has collected supports from 150 thousands Facebookers and was successfully "forced" the authority to release Prita from the prosecutor's captivity. The second case is even more spectacular since Bibit and Chandra 
received more than 1.2 millions supports from Facebookers. The police then released Bibit-Chandra after putting them in detention for four days.

This paper indicates the emergence of new civil society reflected by the cases of Prita and Bibit-Chandra. In these cases, people used the Internet as a means to articulate the public interests. Facebook was used as an instrument to mobilize mass and to pressure the authorities. However, some distinctive features can be found in the two cases in areas such as popular support, government response, and the response of political parties in the House of Representative. This paper will analyze the dynamics of social political movements and will highlight some distinctive features that differ these cases significantly.

\section{DISCUSSION}

The Internet and Civil Society: Theoretical Framework

Civil society can be defined in many ways. Kubik (2000, p. 181-3) mentions three basic types of the definitions of civil society: civil society as a normative idea, civil society as a public space, and civil society as a set of social groups. As a normative idea, civil society refers to a desirable vision of the right form of associationism in a modern society. Such a definition is used in philosophical debates on the society's ideal self-organization beyond the control of the state. As a public space, it refers to a space that is institutionally protected from the state's autocratic intervention within which individuals can have a freedom of association. As a set of social groups, it consists of members who act together to reach common goals. However, Kubik underlines that a civil society has to be a secondary group and transparent with three distinct characteristics: a horizontal interpersonal network, a democratic deliberative structure, and the tolerance of other similar groups and readiness to make collaboration or competition with them according to particular rules based on a mutual respect.

Rather than defining civil role in terms of social identity, Brysk (2000, p. 153) prefers to define civil society in terms of its civic role. He argues that civil society is a public and political association outside the state whose political role is not just to aggregate, to represent, and to articulate interests, but also to create citizens and to shape consciousness. According to Brysk, civic actors in civil society are nongovernmental and nonprofit. They build social capital and act as mediators between the state and private citizens. This definition of civil society confirms another definition of civil society by Put- 
nam (in Edwards and Foley, 2001, p. 7) who identifies a strong civil society with high levels of civic engagement and political culture.

Nowadays, people are witnessing a new form of civic or political engagement. Such an engagement is a result of the advance of technology, in particular the Internet. The Internet has changed the way people communicate each others. It is not only a source of information but also a medium of communication. The Internet has been a virtual public space where people can communicate easily regardless of geographical differences. A research conducted by Pew Internet and American Life Project (2009, p. 5) discovers that $33 \%$ of internet users had a profile on a social networking site and that $31 \%$ of them had engaged in civic or political activities such as signing up as a "friend" of a political candidate or joining a political group on the site.

These new civic engagements have a potential to generate what several scholars (Kittilson \& Dalton, 2008, p. 3; Charoters, 2000, p. 22) called "virtual civil society". As Levine (2000, p. 1) says, civil society has been moving to the Internet. Various organizations use their websites for recruitment public relations, fundraising, internal and external, and other com- munication activities, while citizens channel their aspirations online via email. Kittilson and Dalton (2008, p. 16) argues that virtual civil society seems to have the same benefits for citizen norms and political involvement as conventional civil society. Virtual activities within such a society are related to the norms of civic participatory. Their research also indicates that virtual civil society bridges trust among people beyond their immediate personal network. They believe that interpersonal social group activity in such a virtual society seems to be more conducive to social trust and toleration.

However, there is still a debate on how far the Internet can affect political or civic engagement. Jennings and Zeitner (2003, p. 312) mention two different views on the impacts of the internet on civic engagement. First, a positive vision believes that the Internet has a power to strengthen civil society and democratic politics in general because it extends the opportunities for mobilization and communication. Second, a skeptical vision believes that the Internet will generally preserve and strengthen inequalities in civic engagement because of the "digital divide" regarding the different access of the Internet. The second view sees that people with greater current skills and re- 
sources will simply use the Internet as another tool to perpetuate and exaggerate the inequalities.

The second view is supported by the most current research on the Internet and civic engagement in the America conducted by Pew Internet and American Life Project (2009). The research shows that the Internet has not changed the socioeconomic character of civic engagement in the United States. This research discovers that conventional political activities are still the domain of well educated and wealthy people whether they take place in the real world or on the cyberspace. Individuals with high levels of education and income are more likely to participate in online civic activities than those who have the lower levels of education and income.

A previous study by Kim (2004) on the relationship between individuals' Internet connection and civic engagement also indicates the different levels of scope of participation among three different groups: high, low, and non internet connectors. The high internet connectors' scope of civic participation is generally broader than that of the other groups. In terms of neighborhood belonging, the group of low Internet connectors shows the lowest level of neighborhood belonging. This study also indicates an obvious interaction effect on Internet connectedness and integrated connection to neighborhood storytelling. However, this study highlights, there is no significant difference among the three groups in terms of collective efficacy.

Warf and Grimes (1997) gives an important point of view on the Internet and counter hegemonic discourse. They argue that the Internet does not necessarily serve for either hegemonic or counterhegemonic purposes. It can be oppressive as well as emancipatory. Unfortunately, those who may benefit the most from emancipative uses of the Internet may have the lowest access to it. Hence, the Internet may become an ineffective alternative for the real world's politics.

\section{Two Tales: Prita and Bibit-Chandra The Case of Prita Mulyasari}

In 2009, Prita Mulyasari was a 32 years old woman and a mother of two. She was a patient at Omni International Hospital, a private hospital in Tangerang, one of the Jakarta's suburban areas. She wrote an email and shared her experience of being maltreated by the hospital. On her email, Prita complained about the hospital's services, in particular about the doctor's wrong diagnose that she got a dengue fever. In fact, it was not a dengue fever. The email was originally sent to ten of her friends, but it then spread to other 
hundreds of email recipients and circulated widely and rapidly on numerous social networking sites (SumbawaNews, 4 June 2009; Koran Tempo, 28 May 2009; Viva News, 6 June 2009).

Responding to the spread of the email, the hospital took legal action and charged Prita with defamation. Prita lost a civil case and was ordered to pay Rp. 261 million fine $(\$ 37,500)$. Unfortunately, this fine was not enough. Prita has also to deal with a criminal case after being named a suspect of violating Article 27 of the Electronic Information Transaction Law and Articles 310 and 311 of the Indonesian Criminal Code. The Tangerang prosecutors decided to detain Prita in the Tangerang women prison prior to her trial. Prita was then arrested and detained in the prison on May 13, 2009 (Koran Tempo, 28 May 2009; Herald Sun, 4 June 2009).

The detention of Prita was not attracted public's attention until a Facebook group made to support her. More than 150,000 people signed up as Prita's supporters in the group calling for her immediate release. Prita's story immediately became a hot topic. Almost all national and local media covers her story during the first weeks of June 2009 (detikNews, 2 June 2009; Kompas, 3 June 2009; DetikNews, 5 June 2009). The authorities (i.e., Tangerang prosecutors) received a strong public pressure to release Prita from detention. After being in custody without charge for three weeks, Prita was eventually released and put under "city arrest" prior to her trial (DetikNews, 3 June 2009).

\section{The Case of Bibit - Chandra}

Bibit Rianto and Chandra Hamzah were deputy chiefs of the Corruption Eradication Commission (KPK). They were arrested by the State Police on charges of alleged power abuse and extortion related to a graft investigation against Anggoro Widjojo, a fugitive businessman who was currently in Singapore (Jakarta Post, 13 July 2009). The police initially suspected Bibit and Chandra had received bribes from Anggoro in return for dropping him a suspect in his graft case. However, after failing up to collect enough evidence of bribery, the police named Bibit and Chandra as suspects for acting beyond their authorities - that is, issuing a travel ban for Anggoro and another corruption suspect, Djoko Tjandra.

Anggoro was a director of Masaro Radiokom Ltd. He was allegedly involved in a bribery case revolving around the Ministry of Forestry's radio communication system (SKRT) procurement project whose total budget reached Rp 180 billions (US\$ 12.72 millions). Anggoro was 
named a suspect of having bribed Yusuf Erwin Faishal and three other former members of parliament who worked in the House of Representatives' commission on the forestry and agricultural sectors. The court has sentenced Yusuf to four and half years in jail, while Anggoro still remain fugitive.

It is interesting to note that after declaring Bibit and Chandra as suspects, the State Police did not directly detain them. The police decided to detain them one month later because they fear these KPK leaders could "sway public opinion" by holding press conference (Jakarta Globe, 29 October). Bibit - Chandra's lawyers believed that this reason was unacceptable and non-juridical (Hukumonline, 2 November 2009). According to them, people could not be arrested just because they make a press conference. Regarding the police's reasons for naming Bibit and Chandra as suspects, Abdullah Hehamahua, an advisor of KPK, said that the police took an incorrect procedure. He assumed that the police did not consider the Indonesian Law on KPK which allows KPK to ban a corruption suspect from travelling overseas. What KPK members did to Anggoro was legal and was not an abuse of power. Mahfud MD, a chairman of Indonesian constitutional court, also said that the issuance of a travel ban by KPK for a corruption suspect is not a crime (Jakarta Globe, 22 September 2009).

The public believed that there was a conflict of interest behind this detention (Antara News, 31 October 2009). Susno Duadji, a chief of the police detective bureau, has allegedly involved in a corruption case investigated by KPK. He was caught in a telephone conversation with a target of KPK's investigation. Susno claimed that KPK abused its wire-tapping powers (Detik News, 30 June 2009). KPK argued that it had not tapped Susno. KPK says that its members just picked up Susno's conversation when he called a suspect in one of the KPK's corruption investigations (Detik News, 27 September 2009).

This "conflict" was nationally known as a conflict between the crocodile and the gecko. The use of these words (i.e., crocodile and gecko) to describe such a conflict was originally from Susno. In an interview session by a national magazine (i.e., Majalah Tempo), Susno was asked about his response regarding the KPK's wire-tapping, Susno described the police as "crocodile" and KPK as "gecko". He said, "If there is a comparison, the metaphor is a crocodile on one 
hand and a gecko on the other hand. The gecko is going up against the crocodile. Does the crocodile become angry? No, he does not. He simply regrets that the gecko is being stupid" (Tempo, 6 July 2009). Several weeks after the words "geckocrocodile" became popular among the public, the police proclaimed the two leaders of KPK (i.e., Bibit and Chandra) as criminal suspects and finally put them into the police headquarters' detention.

The detention of Bibit and Chandra drew public reactions and sympathies. Several national figures including former president Abdurrahman Wahid and religious leaders expressed their supports for Bibit and Chandra. A Facebook group calling for their immediate release was made on the day they were arrested by the police. The group amazingly got many supports from Indonesian Facebookers. More than one million Facebookers joined the group and called for the release of Bibit-Chandra. In the group's wall, the Facebookers criticized the detention of Bibit and Chandra and asked the police to release them as soon as possible. Because of this mounting public pressure, the police finally release the two KPK leaders after detained them in the police headquarters for four days (Jakarta Globe, 3
November 2009; Jakarta Globe, 4 November 2009).

\section{The Emergence of New Civil Society}

The civic engagements in these two cases illustrate what Kittilson and Dalton (2008, p. 3) call "virtual civil society". It was civil society because, as indicated by Brysk (2002, p. 153), people did not only move together to articulate their interests, but also to shape their consciousness. Civic actors in these cases were nonprofit and nongovernmental. It was "virtual movement" because people used the Internet to channel their aspirations and to reach their goals. In these cases, they used Facebook as a means of promoting civic movement. Using the framework as defined by Putnam (in Edwards and Foley, 2001, p. 7), these people's movements can be classified as a strong civil society because of the high number of Facebookers involved in the movements. While the number of Facebookers supported Prita reached 150 thousand people, the number of supporters for Bibit and Chandra reached over one million Facebookers.

In both cases, people did the same action for the same goals - that was, using online media to free people, whom they considered as the "victims" of a legal system, from the authorities' detention. In the 
first case, the victim (i.e., Prita) dealt with the issues of the freedom of expression and the need for good health services. In the second case, the victims (i.e., Bibit and Chandra) dealt with the issue of corruption, which is considered as an extraordinary crime in the country. Both cases attracted public attention because the issues were closely related to public affairs.

The Prita's case might be personal as she dealt with her own doctors and the hospital. She was disappointed with the hospital's services and she shared her complaint with other friends on the Internet because she failed to get a satisfying explanation from the hospital. Yet, this problem was actually a problem for many Indonesian patients (Suara Karya, 20 November 2006; Pontianak Post, 13 Oktober 2001; Sinar Indonesia Baru, 5 Oktober 2007). Some of them articulated their complaints in the media, and many more others might not do the same thing because of their limited access to the media. Here, Prita's complaint on public health services was actually a representation of the disappointment of many patients and their families.

A strong public support for Prita was not only because she represent the interests of unsatisfied patients, but also because she constituted the martyr of the freedom of expression. Prita was jailed because of her complaint email. Many people, including former vice president Jusuf Kalla (Kompas, 3 June 2006), considered the charges against Prita as "unfair" since she just shared her experience to her friends via an email. Prita was named a suspect of violating Article 27 of the Electronic Information Transaction Law. The article says that everyone intentionally and illegally distributes or transmits or makes accessible electronic information and or an electronic document that contains humiliation can be sent to jail for maximum 6 years and or 1 billion rupiahs. Prita's supporters argued that this article can hinder the process of democratization in Indonesia. The article might discourage people to critique or to complain poor public services in the country. The punishments attached to the article might make people afraid of expressing their feedbacks or comments regarding public services they received. The Prita's case gave a chance to the public to challenge and to question such a clause of law. To them, a law should protect citizens' rights, not the opposite (Okezone, 16 June 2009).

Similar to the Prita's case, the case of Bibit-Chandra drew public attention because it was related to the issue of cor- 
ruption, which is one of the most challenging problems in the country (Jakarta Post, 31 October 2009). Bibit and Chandra were not charged on a corruption crime, but their positions as deputy chairperson of KPK made people worry about the future of corruption eradication in Indonesia. The public suspiciously thought that the detention of these KPK leaders was part of a strategy to weaken this anticorruption body. Comments written in the wall of the Facebook group illustrated that some people view this detention as a product of a high level conspiracy to weaken KPK (Banjarmasin Post, 31 October 2009). A statement made by 32 NGOs in East Java also confirmed public suspicion about such a conspiracy to weaken this corruption eradication commission (Viva News, 3 November 2009).

People also questioned the reasons for why the police detained Bibit and Chandra (Media Indonesia, 30 October 2009; Detik News, 29 October 2009). The police decided to detain them because they fear these KPK leaders could "sway public opinion" by holding press conference (Jakarta Globe, 29 October). Legal observers saw this reason was unacceptable and non-juridical. According to them, people could not be arrested just because they make a press conference (Harian
Global, 3 November 2009; Antara News, 29 October 2009). The proponents of Bibit-Chandra also believed that the police's arguments to name these KPK leaders as suspects were not convincing. As is mentioned above, the police initially suspected Bibit and Chandra had received bribes from Anggoro in return for dropping him a suspect in his corruption case. After failing up to collect enough evidence of bribery, the police then named Bibit and Chandra as suspects for acting beyond their authorities (i.e., issuing a travel ban for Anggoro, a fugitive businessman and a corruption suspect). Mahfud MD, a professor of legal studies and a chairman of Indonesian constitutional court, argued that the issuance of a travel ban by KPK for a corruption suspect is not a crime (Jakarta Globe, 22 September 2009).

As far as civic movement is concerned, three similarities can be observed from the two cases. First, people used Facebook as a means to get popular support and to pressure the authorities. In the two cases, Facebook became an efficient and effective means to send their message and was one of the crucial factors forcing authorities to release Prita, Bibit and Chandra from their detention. Second, as can be seen from comments written on the wall of Facebook groups, people consid- 
ered Prita and Bibit - Chandra as the oppressed and the victims of legal system. In the case of Prita, people viewed Prita as a victim of the article 27 of the Electronic Information Transaction Law, which was mistakenly interpreted (Sukemi, 2009). In the case of Bibit - Chandra, people accused the police of having mistakenly named the KPK leaders as suspects (Jakarta Globe, 22 September 2009; Harian Global, 3 November 2009; Antara News, 29 October 2009). People also viewed Prita, Bibit and Chandra as their heroes and the representatives of public interest. Prita was considered as a personification of the freedom of expression and the need for good public services, while Bibit and Chandra were considered as the heroes of corruption eradication. Third, the media involvement was very strong in the two cases. The media blew up the cases and continuously updated the increase number of Facebookers supporting the cases as well as quoted Facebookers' comments written in the Facebook walls. The Internet and the media played an important role in pressuring the authorities and in shaping people consciousness.

Hence, referring to Jennings and Zeitner's view (2003, p. 312) on the impacts of the internet on civic engagement, the Internet has played a significant role in promoting civil society. With the support from media (e.g., TVs, newspapers, radios), the cyber communities using Facebook has successfully mobilize popular support and has effectively pressured the authorities to listen to their voices. Warf and Grimes (1997) argue that the Internet can be oppressive as well as emancipatory. It does not necessarily serve for either hegemonic or counter-hegemonic purposes. Yet, in these two cases, the Internet acted as an emancipative instrument and served for counter-hegemonic purposes.

\section{Same Models, Different Features}

Although the two cases shared similar characteristics, they also have distinctive features. First, they differ significantly in the number popular support. Prita got supports from 150 thousand Facebookers, while Bibit - Chandra got more than one million Facebookers' supports. It seemed that the more people consider "the victims" as the representatives of public interests, the higher supports they give to "the victims". In the first case, the victim (i.e., Prita) fought against the freedom of expression and the need for good health service. In the second case, the victims (i.e., Bibit and Chandra) fought against corruption, which is considered as an extraordinary crime in the country. 
The support for the second victims was much higher than that for the first victim because of the difference in nature of the problems experienced by the victims. In the first case, although Prita can be a representation of public interests (i.e., the freedom of expression and the need for good public service), the victim actually dealt with her personal affairs. She complained the hospital service and shared it with her friends online. In the second case, Bibit and Chandra acted public figures. They represented a state agency (i.e., $\mathrm{KPK}$ ) issuing a travel ban for a corruption suspect, an action which became a basic argument for the police to name them as suspects. People viewed that the detention of these KPK leaders will hinder KPK's efforts to eradicate corruption in the country. Even, some of them believed that such a detention was part of a systematic effort to weaken KPK. These views encouraged more people to support KPK and to call for the KPK leaders' immediate release.

Second, the government responded to the issues differently. In the case of Prita, the government responded the issue very quickly. President Yudhoyono, in the midst of an election campaign, has called on the police, the prosecutors and the courts to be lenient and to consider public justice (Tempointeraktif, 3 June
2009).Vice President Jusuf Kalla, who was running against President Yudhoyono in the July presidential elections, described the charges against Prita as "unfair" and asked the legal authorities to release her from detention (Viva News, 3 June 2009). In the case of Bibit-Chandra, no comment made by President Yudhoyono or Vice President Boediono to explicitly support Bibit-Chandra. An explanation was given the Minister of Communication and Information, Tifatul Sembiring, saying that President Yudhoyono did not want to intervene in any legal process (Kompas, 30 October 2009).

Such a different response was a result of the differences in the political context and the complexity of the issues. It is important to note that the case of Prita became so popular during May and June 2009, which was a period of the 2009 presidential campaign. In this context, it was understandable why all the Indonesian presidential candidates and their teams want to gain political benefits from public comments to support Prita. Megawati Soekarnoputri who was not in the government and was also a president candidate made her visit to the Prita's detention to show her support. This political context made the detention of Prita much 
more interesting to political elites than the detention of Bibit-Chandra. While the former happened during the presidential campaign, the latter happened just nine days after SBY was inaugurated as the President for the second term.

Complexity of the issues might also influence the government's responses to the cases. The Prita's case is much simpler than the Bibit-Chandra's case. Unlike the case of Prita, which was more personal and merely involved her personal complaints with the services of a private hospital, the case of Bibit-Chandra was more institutional and involved rivalry between state agencies (Viva News, 11 November 2009). The case of Bibit and Chandra was about corruption and the public trust to the government institution.

As far as corruption practices among state agencies are concerned, the image of Indonesian Police was not really good among Indonesian society. According to Transparency International Indonesia's 2008 Survey (TII, 2009), the State Police was the most corrupt institution in Indonesia with a corruption perception index of 4.8. The survey also revealed that the business community saw the police as the most bribe-riddled institution in the country. A similar survey conducted in 2007 by TII showed the same thing - that is, the police was the most corrupt state agency with a corruption index of 4.2. The detention of two KPK leaders made the police's image even worse. This encouraged more public support to Bibit and Chandra and made the number of Facebookers signing up as their supporters continued to increase even after they had been released (Solo Pos, 9 November 2009).

Third, the difference can also be seen in the response of political elites in the House of Representative (DPR). Responding to the Prita's case, the voice of DPR was similar to the voice of the public. The DPR's Commission IX, which was a commission on health affairs, called the hosptal's management for public hearing session. At the end of the session, the commission insisted the government to revoke the hospital's operational permit. They also asked the management to apologize to Prita and to withdraw its suit against her (Viva News, 8 June 2009).

A similar response could not be found in the case of Bibit and Chandra. The voice of DPR in this case was not in line with the aspiration of the Public. Instead of supporting KPK, in a hearing session with the police, the DPR's Commission III insisted the police to continue with the case. This commission on legal affairs argued that they did not want to 
stand in one's side, but to encourage law enforcement in the country (Detik News, 8 November 2009). This difference was interesting because the more online support in the cyberspace did not really mean the more real support in the House of Representative. In the case of Prita, she got around 150 thousand supports from Facebookers, but she got a full support from the House of Representative. In the case of KPK, Bibit and Chandra got more than one million supports from Facebookers, but they did not get any support from the House of Representative. There were a number of members of the House showing their individual supports for Bibit and Chandra. However, this was an individual, not an institutional support in a formal meeting.

Such a response of the DPR's commission III raised criticism from the public (Jawa Pos, 8 November 2009). Critiques also came from Facebookers (Detik News, 9 November 2009). They made another special Facebook group to articulate their disappointments. Around 64 thousands Facebookers has signed up as the members of this online group. To these Facebookers, DPR has failed to function as the representative of the Indonesian people. They said that DPR has showed an insulting drama to the people of Indonesia
(Detik News, 8 November). As a response of this critique, the commission changed their stand. In the following public hearing with the Attorney General, it gave a statement asking the authorities to stop the case (Solo Pos, 9 November 2009; Solo Pos, 18 November 2009).

A weak response of DPR (i.e., Commission III) and a strong support of Facebookers (i.e., around 1.3 million Facebookers supporting Bibit-Chandra) encouraged many media to think of what they called "online parliament" (Okezone, 8 November 2009; Suara Merdeka, 9 November 2009; Kompasiana, 10 November 2009; Joglo Semar, 12 November 2009). It is not a conventional parliament that offers online public services. It refers to a cyber community who engages in political activities to control and to balance traditional political powers.

The response of Indonesian Facebookers to the cases of Prita and BibitChandra and their success stories in controlling the authorities indicate a significant existence of an "online parliament". Such an online parliament signed an emergence of a new civil society movement in modern Indonesia. As a political entity, this online parliament has several advantages. It is much more inexpensive and independent compared to convention- 
al parliament. It can be an efficient and effective means to reach political goals. People can just sit in front of their computers or use other similar electronic devices to engage in a civic movement. However, it also has several disadvantages. Such an online parliament might be only work for political or public issues that attract much public attention. Issues that only interest a small portion of community members will not make an online parliament able to influence a public policy. In addition, this online parliament is only accessible for people who have access on the Internet. Unfortunately, as is shown by many studies (Pew Internet and American Life Project, 2009; Kim, 2004; Warf and Grimes, 1997), the number of people having access to the Internet is much smaller than those who do not access on it.

\section{CONCLUSION}

The cases of Prita and BibitChandra reflect an emergence of new civil society movement in modern Indonesia. In both cases, people did the same action for the same goals - that was, using online media to free people from the authorities' detention. These cases attracted public attention because the issues were closely related to public affairs. Prita was consid- ered as a representative of the needs for good public services and the freedom of expression. Bibit-Chandra drew public attention because their strong relationship with the efforts of corruption eradication in the country.

As far as civic movement is concerned, three similarities can be observed from the two cases. First, people used Facebook as a means to get popular support and to pressure the authorities. Second, both Prita and Bibit - Chandra were widely considered as the oppressed and the victims of legal system. They were also considered as the representatives of public interests. Third, the media involvement was very strong in these cases. The media blew up the cases and continuously updated the increase number of Facebookers supporting the cases. The Internet and the media played an important role in pressuring the authorities and in shaping people consciousness.

However, several distinct features can also be found in the cases. First, they differ significantly in the number popular support. Bibit-Chandra got more supports than Prita. Although Prita constituted a representative of public interests (i.e., the freedom of expression and the need for good public service), she actually dealt with something more personal than that 
was dealt by Bibit-Chandra. Second, the government was more responsive in the case of Prita than that of the case of BibitChandra. This difference was a result of the differences in the political context and the complexity of the issues. Third, the representativeness of the House of Representative differs in both cases. In the case of Prita, the voice of DPR was similar to the voice of the public. Meanwhile, in the case of Bibit and Chandra, their voice of DPR was not really in line with the aspiration of the Public.

The response of Indonesian Facebookers to the cases of Prita and BibitChandra and their success stories in controlling the authorities indicate a significant existence of the so-called an "online parliament", which signed an emergence of a new civil society movement in modern Indonesia. As a political entity, this online parliament is much more inexpensive and independent compared to the conventional parliament. However, it might only work for political issues that attract much public attention and might be only accessible for those who have the access to the Internet.

\section{BIBLIOGRAPHY}

Brysk, A., 2000. "Democratizing civil society in Latin America”, Journal of
Democracy, Vol. 11, N. 3, pp. 151 165

Charoters, T. 2000. “Civil society: Think again”, Foreign Policy, Winter 1999 -2000, p. 18-29

Jennings, M. K. and Zeitner, V., 2003. "Internet Use and Civic Engagement: A Longitudinal Analysis", Public Opinion Quarterly, Vol. 67, pp. $311-334$

Kittilson, M. C. and Dalton, R. J., 2008. "The Internet and virtual civil society: The new frontier of social capital". UC Irvine: Center for the Study of Democracy, retrieved 2 November 2009, from: http://escholarship.org/uc/item/2cj1c $67 \mathrm{k}$

Kim, Y. C. 2004. "Internet connectedness and civic engagement: A multilevel approach", Paper presented at the annual meeting of the International Communication Association, New Orleans Sheraton, New Orleans LA, May 27, retrieved 13 November 2009, from http://www.allacademic.com/meta/p 112812_index.html

Kubik, J. 2000. "Between the state and networks of "cousins": The role of civil society and noncivil associations in the democratization of Po- 
land", in Nancy Bermeo and Philip Nord, Civil Society before Democracy, Lanham: Rowman and Littlefield, 2000, pp. $181-207$

Levin, P. 2000. “The Internet and civil society", Philosophy \& Public Policy, Vol. 20, No. 4, University of Maryland: College of Public Affairs, retrieved 13 November 2009, from http://www.puaf.umd.edu/ippp

Pew Internet and American Life Project, 2009. "The Internet and civic engagement", September, retrieved 2 November 2009, from: http://www.pewinternet.org/Reports /2009/15-The -Internet-and-CivicEngagement.aspx

Sukemi, 2009. "Kesalahan dalam memahami UU ITE", Okezone.Com, Rabu 17 June, retrieved, 28 November, from http://suar.okezone.com/read/2009/0 6/17/58/230086/kesalahan-dalammemahami-uu-ite

TII, 2009. Measuring corruption index in Indonesia: Indonesia corruption perception index 2008 and bribery index, Jakarta: Transparency International Indonesia, retrieved 30 November 2009, from http://www.ti.or.id/en/publication/84 /tahun/2009/bulan/01/tanggal/21/id/ $3845 /$

Warf, B. and Grimes, J., 1997. "Counter hegemonic discourses and the Internet”, Geographical Review, Vol. 87, No. 2, Cyberspace and Geographical Space, pp. $259-274$

\section{Newspapers, e-News:}

1. Prita's Case

DetikNews, 2 June 2009, "Bebaskan Prita gencar di Facebook"

DetikNews, 3 June 2009, "Prita Mulyasari bebas dari penjara"

DetikNews, 5 June 2009, "Dukungan di Facebook hampir mencapai 150 ribu anggota"

Herald Sun, 4 June 2009, "Prita Mulyasari faces jail over email complaint"

Koran Tempo, 28 May 2009, “Mengeluh lewat milis, ibu rumah tangga ditahan"

Kompas, 3 June 2009, "Prita: Saya ingin pulang"

Kompas, 3 June 2009, "Wapres: Polisi harus adil soal Prita"

Okezone, 16 June 2009, "Prita korban pertama UU ITE"

Pontianak Post, 13 Oktober 2001, "Surat pembaca: Kecewa terhadap layanan RS Dr. Soedarso" 
Sinar Indonesia Baru, 5 Oktober 2007, "Kecewa pelayanan RSUD Sidikalang, keluarga pasien marahmarah"

Suara Karya, 20 November 2006, "Suara pembaca: Kecewa atas pelayanan RS Jantung Harapan Kita"

SumbawaNews, 4 June 2009, "Inilah kronologis kasus Prita Mulyasari”

Tempointeraktif, 3 June 2009, “SBY ikut komentari kasus Prita Mulyasari”

Viva News, 6 June 2009, "Prita trauma menulis email"

Viva News, 3 June 2009, “Jusuf Kalla: Kenapa kirim email masuk penjara"

\section{Bibit-Chandra's case}

Antara News, 31 October 2009, “KPK deputies' arrest sparks speculation about police's motive"

Antara News, 29 October 2009, "Penahanan Chandra karena konferensi pers tidak logis"

Banjarmasin Post, 31 October 2009, "Bibit \& Chandra dapat dukungan 74 ribu Facebookers"

Detik News, 29 October 2009, "Polri harus beberkan alasan penahanan yang rasional"
Detik News, 27 September 2009, "Bibit: Bukan kita menyadap, Susno-nya yang masuk ke penyadap kita"

Detik News, 30 June 2009, "Komjen Susno: Menyadap semua orang itu penyalahgunaan kekuasaan"

Detik News, 8 November 2009, “Komisi III dukung Polri tuntaskan kasus Chandra-Bibit"

Detik News, 8 November 2009, "Muncul gerakan 'sejuta Facebookers kecam komisi III DPR'”,

Detik News, 9 November 2009, "Kesalahan ketua komisi III yang bikin dikritik jamaah Facebook"

Harian Global, 3 November 2009, "Penahanan Bibit - Chandra dan blunder Polri"

Hukumonline, 2 November 2009, "Penahanan Bibit - Chandra: Alasan polisi 'konyol' dan bukan alas an yuridis"

Jakarta Post, 13 July 2009, "Fugitive Anggoro Widjaja spotted in Singapore"

Jakarta Post, 31 October 2009, "Public Support KPK deputy chairmen"

Jakarta Globe, 29 November 2009, "KPK's Chandra Bibit arrested"

Jakarta Globe, 3 November 2009, "Indonesia antigraft deputies Bibit Chandra released" 
Jakarta Globe, 4 November 2009, "Released KPK Officers Bibit and Chandra Overwhelmed By Public Support"

Jakarta Globe, 22 September 2009, “Indonesian antigraft body KPK plans strong action against police"

Jawa Pos, 8 November 2009, "Di balik layar rapat kerja komisi III dengan kapolri"

Joglo Semar, 12 November 2009, "Parlemen online, tantangan bagi anggota DPR"

Kompas, 30 October 2009, "Tifatul: SBY tak campuri soal Bibit dan Chandra"

Kompasiana, 10 November 2009, "Menimbang Parlemen Online"

Media Indonesia, 30 October 2009, "Polri diminta transparan soal penahanan Bibit dan Hamzah"
Okezone, 8 November 2009, “Kekuata parlemen online"

Solo Pos, 9 November 2009, "Dukungan Facebookers Bibit-Chandra terus menguat"

Solo Pos, 9 November 2009, "Takut tuai kecaman masyarakat, komisi III berubah sikap"

Solo Pos, 18 November 2009, “Komisi III minta Polri dan Kejagung hentikan kasus Bibit-Chandra"

Suara Merdeka, 9 November 2009, "Fenomena parlemen online"

Tempo, 6 July 2009 “Susno Duadji: Cicak kok mau melawan buaya"

Viva News, 11 November 2009, “Todung: Antara mafia hukum and rivalitas"

Viva News, 3 November 2009, “LSM seluruh Jatim turun ke jalan hari ini” 